急性肝不全モデルにおけるセロトニンおよびトリプタミン代謝 一肝臓内，脳内执よび腎臓内に拈けるトリプトファン

扣よび代謝産物の変化一

\begin{tabular}{|c|c|c|c|c|c|}
\hline 靖紘 & 児玉 & 千枝 & 河田 & 則文 & 阪上 \\
\hline 守一 & 小林 & 絢三* & 山本 & 祐夫** & 森沢 \\
\hline
\end{tabular}

要 旨：嫌気性グラム陽性菌である Propionibacterium acnes 加熱死菌をマウスに静注して， 7 日後にグラム陰性菌由来の lipopolysaccharide(LPS)を静注すると，ほとんどのマウスは広 範な肝細胞壊死を伴って24時間以内に死亡する.この急性肝不全モデルマウスにおける肝臟内， 脳内および腎臓内のトリプトファン代謝について検討した。その結果, トリプトファンが著し く上昇し，トリプタミン経路，セロトニン経路の代謝促進が認められた，特に脳に和いてはセ ロトニン代謝よりるトリプタミン代謝, 特にインドール酢酸の増加率が大きかった。

索引用語： 急性肝不全 トリプトファン セロトニン インドール酢酸 トリプ

\section{緒 言}

トリブトフォン (TRP) は不可欠フミノ酸であり， 多くは蛋白合成に利用されるが，その代謝産物には重 要な生理学的活性を示するのがある.TRPの主要な代 謝経路としてはインドール核の開裂にはじまる経路と 側鎖の短縮にはじまる経路があり，前者では中間体々 してキヌレニンが形成され，NADあるいはフセチル $\mathrm{CoA}$ と代謝され，後者では神経伝達物質として重要な セロトニン(5-hydroxytryptamine, 5HT)が作られる. このほか, TRPが脱炭酸されてトリプタミン(TRM) からインドール酢酸 (IAA)やトリプトホール(TOL) が生じる経路も存在する.

従来, TRP から IAA が形成される代謝経路は微生 物や植物に強いとされているが，臨床的にはある種の 遺层病, 糖尿病, 自然発生スプレー, 神経括上び筋疾 患, 早期の肝癌打よび萃臓癌などで尿中に IAA が増加 することが報告されている(12).ところで, TRPからの 主代謝経路であるキヌレニンへの代謝は，まず肝葴に 局存する、トリプトファンビロラーゼにより行われる. このことは, TRPの代謝に肝滅が重要な役割を担らこ

* 大阪市立大学医学部第 3 内科

**大阪社会医療センター

****大阪市立大学医学部第 1 生化学

<受付日63年 2 月 15 日 $>$
とを示し, 肝喴の障害はとりる直さず, キヌレニン経 路のみでなく，5-HT および TRM 経路にも多大な変 動をもたらすと考えられる。事実, 肝障害に执いて TRP, およびその代謝産物のレベル変動が示されてい $ろ^{4,5)}$. 著者らもガラクトサミンによる実験的肝障害も デルラットにおいて血清中の IAA レベルが障害初期 において，上昇すること到，また劇症肝炎患者血清中の IAAが上昇することを報告した7?.

さらに, 重篤な肝障害時にみられる肝性昏睡に TRP の代謝産物である5-HTが関与するとの推測もあ る $^{8,9)}$. TRM は 5-HT と化学構造が大変類似し, しかも 近年神経伝達物質や neuromodulator としての役割が 示唆されている(10). このことは TRM 代謝産物と肝性 脳症との関連が示唆され，大変興味が持たれる。

一方, 著者らはマクロファージ系細胞を肝に動員し, 活性化することにより肝細胞障害が誘導されることを 明らかにし, この実験的急性肝不全に, 活性化マク口 ファージあるいは活性化 Kuffer 細胞が何らかの役割 を果たしている可能性を示した，すなわち，嫌気性ク ラム陽性菌である Propionibacterium acnes (P. acnes)加熱死菌を動物に静注して，一定期間後にクラ ム陰性菌由来の LPS を静注すると、ほとんどの動物は 広範な肝細胞壊死を伴って24時間以内に死亡すること を見出しだ1)。 
本研究では急性肝不全モデルにおける肝葴内，脳内

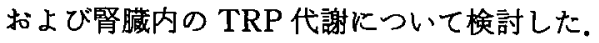

\section{実験方法}

\section{1. 急性肝不全の誘導}

6〜8 週齢の雄性 BALB/c マウスの尾静脈より, P. acnes 加熱死菌1mg を注入し， 7 日後に1 $\mu \mathrm{g}$ の Salmonella enteritidis 由来の LPS (Difco 社製) を追加 静注した。 24時間経過後, 肝を摘出して病理組織学的 に検討した。な和，P. acnesは本学細菌学教室より寄 贈されたものを使用した。

2. 生体試料の採取法

P. acnes 加熱死菌1mg をマウスに注入し，7日後の マウス, P. acnes 加熱死菌1mg をマウスに注入し， 7 日後に $1 \mu \mathrm{g} の$ LPS を追加静注し，死ぬ直前のマウス， あるいは，LPSを追加静注し，24時間後に生存したマ ウスのそれぞれの肝臓，脳および腎葴を採取した。

3.トリプトファン怙よびその代謝産物の高速液体 クロマトグラフィーによる分析

高速液体クロマトグラフィー(HPLC, LC-3A，島津 製作所製）を用い，七ロトニン (5-HT)，5一ヒド口 キシインドール酢酸 (5-HIAA)，トリプトフォン (TRP), トリプタミン(TRM)インドール酢酸(IAA) を同時分析した Zorbax- $C_{B}(4.6 \mathrm{~mm}$, i.d. $\times 25 \mathrm{~cm})$ にプレカラム $(4.6$ $\mathrm{cm}$ ， i.d. $\times 5 \mathrm{~cm}$ )を接続して用いた。 また， injectorは WISP 710B（Waters Association Japan）を用いた。 移動相として楥衝液（50mM 酢酸ナトリゥム：50mM

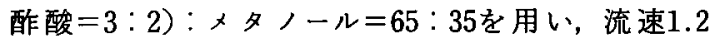
$\mathrm{m} l / \mathrm{min}$ で行った，溶出液中の TRP 量はインドール 骨格に特有な蛍光を $\mathrm{Ex} 280 \mathrm{~nm}, \mathrm{Em} 350 \mathrm{~nm}$ で測定し て定量した。

分析データの処理はクロマトパック C-R1B（島津製 作所製)を用いて行ない，あらかじめ作成した標準曲 線のピークの高さと比較して定量值を算出した。

4. 抽出法

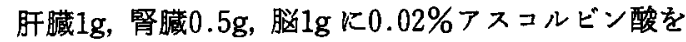
含む $0.1 \mathrm{M}$ 過塩素酸 $\left(\mathrm{HClO}_{4}\right)$ を10容量加え, ホモシ ネートし, $4{ }^{\circ} \mathrm{C}, 12,000 \mathrm{rpm}$ で10分間遠心分離を行い, 上清を得た。沈渣に再度 $0.02 \%$ アスコルビン酸を含む， $0.1 \mathrm{M}$ 過塩素酸を 5 容量加光, 混和し, $4{ }^{\circ} \mathrm{C}, 12,000$ $\mathrm{rpm}$ で10分間遠心分離を行い，得られた上清を前回の 上清と混和し，これを fluoropore (EP-045, poresize $0.45 \mu \mathrm{m}$, size $13 \mathrm{~mm} \phi$ ，住友電気工業株式会社）で沪 過し，HPLC 用サンプルとした。

なお，HPLC の注入量は $100 \mu 1$ とした。

5. 統計処理

実験データは全て mean士SEで示し，統計処理は Students't-testを用いて検討した。

\section{実験結果}

1. 急性肝不全マウスの誘導

P. acnes 加熱死菌を50匹のマウスの尾静脈に注入 し，7 日後に微量の LPS を追加静注するとほとんどの マウスに急性肝不全が誘導された，すなわち，LPS 静 注 1 時間後よりマウスの動きは鈍くなり，2〜3時間 後では触刺激に対してもほとんど反応しなくなった。 4 時間目頃上り痤攀を伴って死亡するマウスが出現 し，24時間後に括ける生存率は $20 \%$ あっった(Fig. 1). 急性肝不全を誘導したマウスについて，䀒の組織像を 光顕的に観察すると，すべてのマウスに広範な肝細胞 の变性抢よび壊死像が認められた。

2. 肝䁍内におけるトリプトフフンおよび代謝産物 の変化

P. acnes 静注 7 日後のマウス（以後対照群と略す）, P. acnes 静注 7 日後に LPS を静注して死亡に至る直 前のマウス（以後死亡群と略す）およびP. acnes 静注 7 日後にLPS を静注して24時間後においても生存し ているマウス（以後生存群と略す）について, 肝缄内 TRP, TRM, IAA， 5-HT おょび5-HIAAの濃度を比 較した。 その結果, Fig. 2 に示すように対照群の TRP

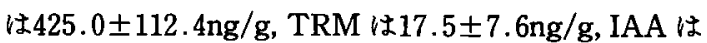

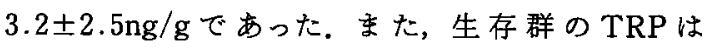
$412.5 \pm 138.4 \mathrm{ng} / \mathrm{g}$, TRM は20.0 $\pm 11.2 \mathrm{ng} / \mathrm{g}$, IAA は $4.8 \pm 7.8 \mathrm{ng} / \mathrm{g}$ であった。一方, 死亡群の TRPは $1062.4 \pm 188.5 \mathrm{ng} / \mathrm{g}, \mathrm{TRM}$ は34.4 $\pm 14.3 \mathrm{ng} / \mathrm{g}, \mathrm{IAA}$ は

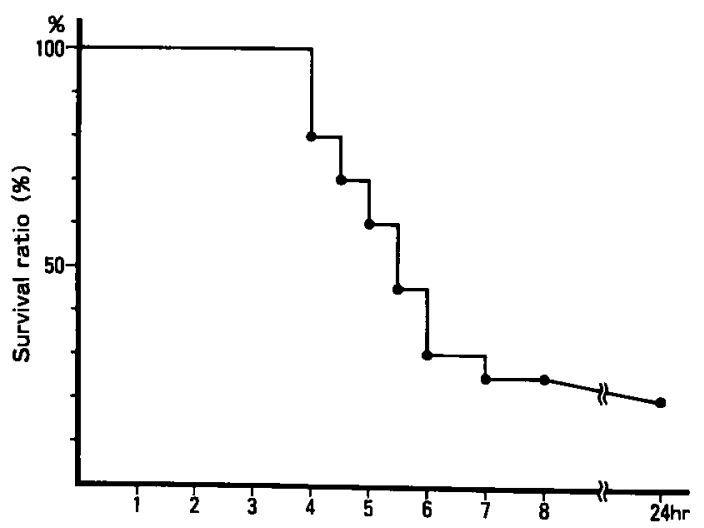

Fig. 1 Survival rate in an experimentally-induced acute hepatic failure model $(n=50)$. 


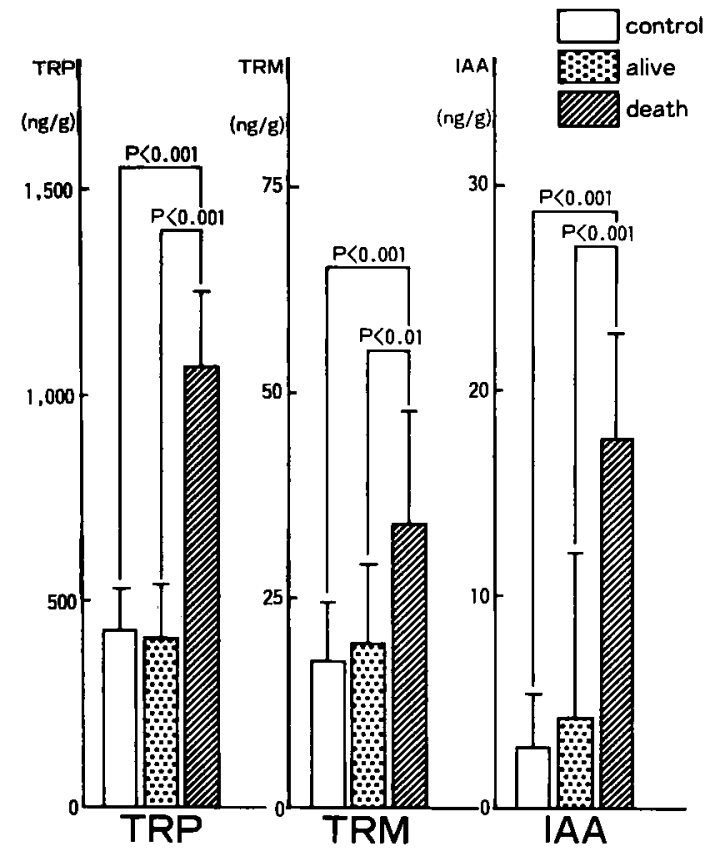

Fig. 2 Change of tryptophan and tryptamine metabolites in liver of mice with acute hepatic failure.

cotrol group; $n=10$, alive group; $n=10$, death group; $\mathrm{n}=10$.

$17.8 \pm 5.2 \mathrm{ng} / \mathrm{g}$ で対照群そして生存群に比して全て著

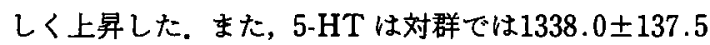
ng/g,であったが 5-HIAA は検出不能であった。 また, 生存群の 5-HT, 5-HIAA は1075.4 $4424.8 \mathrm{ng} / \mathrm{g}, 7.8 \pm$ 9.5ng/gであった。一方, 死亡群の 5-HT, 5-HIAA は $1247.5 \pm 174.8 \mathrm{ng} / \mathrm{g}, 17.8 \pm 17.5 \mathrm{ng} / \mathrm{g}$ で 5-HIAA のみ 対照群に比して著しく上昇した（Fig. 3)。

3、脳内に扣汸るトリプトファンおよび代謝産物の 变化

脳内では対照群の TRPは2.3 $\pm 0.3 \mu \mathrm{g} / \mathrm{g}$, TRM は $3.01 \pm 0.48 \mathrm{ng} / \mathrm{g}$, IAA は30.8 $554.2 \mathrm{ng} / \mathrm{g}$ であった。 た, 生存群の TRPは3.8 $\pm 1.1 \mu \mathrm{g} / \mathrm{ml}$, TRM は $74.8 \pm$ $36.7 \mathrm{ng} / \mathrm{g}$, IAA $29.8 \pm 58.4 \mathrm{ng} / \mathrm{g}$ で対照群に比して TRP およ゙ TRM は著しく上昇した。一方, 死亡群の TRPは $6.7 \pm 3.2 \mu \mathrm{g} / \mathrm{g}$ で対照群そして生存群に比し て全て著しく上昇した（Fig. 4)。また，5-HTお゙よび 5-HIAA は, Fig. 5 に示すよ5に対照群の5-HTは $1.01 \pm 0.07 \mu \mathrm{g} / \mathrm{g}, 5-\mathrm{HIAA}$ は113.2 $\pm 28.3 \mathrm{ng} / \mathrm{g}$, 生存群 の 5 -HTは1.28 $\pm 0.10 \mu \mathrm{g} / \mathrm{g}, 5-\mathrm{HIAA} は 282.5 \pm 67.8$ $\mathrm{ng} / \mathrm{g}$ で対照群に比して共に上昇した。一方, 死亡群の

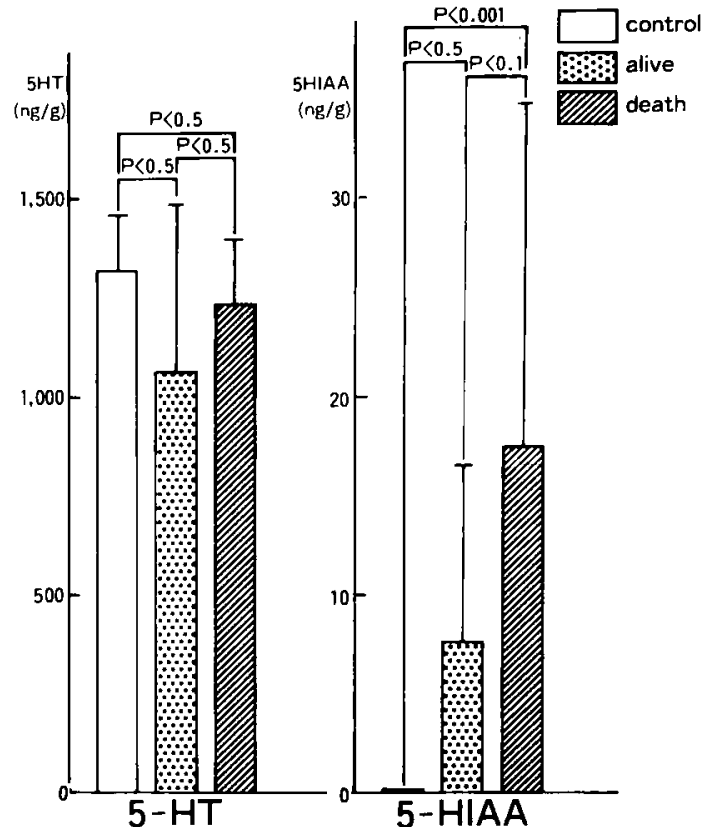

Fig. 3 Change of serotonin metabolites in liver of mice with acute hepatic failure.

control group $; n=10$, alive group $n=10$, death group; $\mathrm{n}=10$.

$5-\mathrm{HT}$ は $1.49 \pm 0.14 \mu \mathrm{g} / \mathrm{g}, 5$-HIAA は339.0 \pm 101.7 $\mathrm{ng} / \mathrm{g}$ で対照群に比して 5-HT，5-HIAA は共に上昇 し, 生存群に比して5-HT は上昇した。

4. 腎㛾内におけるトリプトファンおよび代謝物の 変化

腎葴内の対照群の TRPはFig. 6 に示すように, $4.25 \pm 0.61 \mu \mathrm{g} / \mathrm{g}, \mathrm{TRM}$ は5 $.1 \pm 14.8 \mathrm{ng} / \mathrm{g}$, IAA は検 出不能であった。また, 生存群の TRP, TRM, IAA は対照群に比してわずかに上昇したが，死亡群では TRP, IAA は対照群, 生存群に比して著明に上昇した が，TRM は対照群に比してのみ著明に上昇した。

一方, 対照群の 5-HT および 5-HIAA は, Fig. 7 に 示すように0.48 $\pm 0.02 \mu \mathrm{g} / \mathrm{g}, 25.0 \pm 9 . \mathrm{lng} / \mathrm{g}$ であっ た。また，生存群の 5-HIAA は対照群に比して著明に 上昇し, 死亡群の 5-HT, 5-HIAA は対照群, 生存群に 比して共に著明に上昇した。

\section{考察}

TRP は不可欠フミノ酸であり,蛋白合成の基質とな るばかりでなく, 生理学的に重要な種々の活性物質の 生成に関与する.また，TRPおよび代謝産物は各種の 疾患で変動し，疾患との因果関係が注目されている。 
$18: 1448$

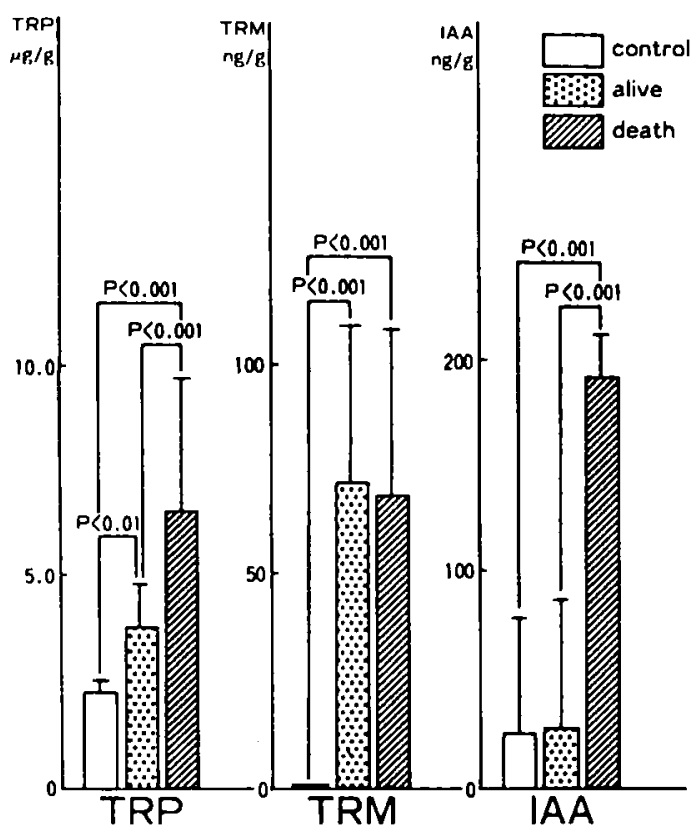

Fig. 4 Change of tryptophan and tryptamine metabolites in brain of mice with acute hepatic failure.

control group; $n=10$, alive group; $n=10$, death group $; n=10$.

例觉ば，近年肝硬変において血中 TRPの上昇がみ られることが報告されている゙). 重篤な肝障害では，乙 ばしば肝性昏睡などの肝性脳症が引き起こさせるが, ヒト肝性聋睡に招いて, 脳内の 5-HT 合成が促進され ることが報告され，肝性昏睡の原因としてTRP 代謝 産物の変動が注目されている5).

さらに, 肝疾患時に芳香族了ミノ酸に由来する微量 のフミンが増加するとの報告すあり，肝性昏睡の誘導 に微量のアミンが関与することが推測されている13). しかし，これらのアミンの生成は微量であり，肝疾患 の因果関係は明らかにされているとはいえない。

今回, 著者らは急性肝不全モデルマウスの肝臓, 脳, 腎臓内の TRP 代謝の変動について検討した。その結 果, 肝葴では死亡群において，TRP，TRM 経路の代 謝産物である TRM, IAA 怙よびセロトニン経路の代 謝産物である 5-HIAA が著しく上年した. 脳では生存 群において，TRP，TRM 打上びセロトニン経路の代 謝産物である5-HT，5-HIAA が著しく上昇した。 た, 死亡群に括いて, TRP, TRM, IAA, 5-HT, 5-HIAA 全て著しく上昇した。な扰，脳に批いては 5-HT 代謝

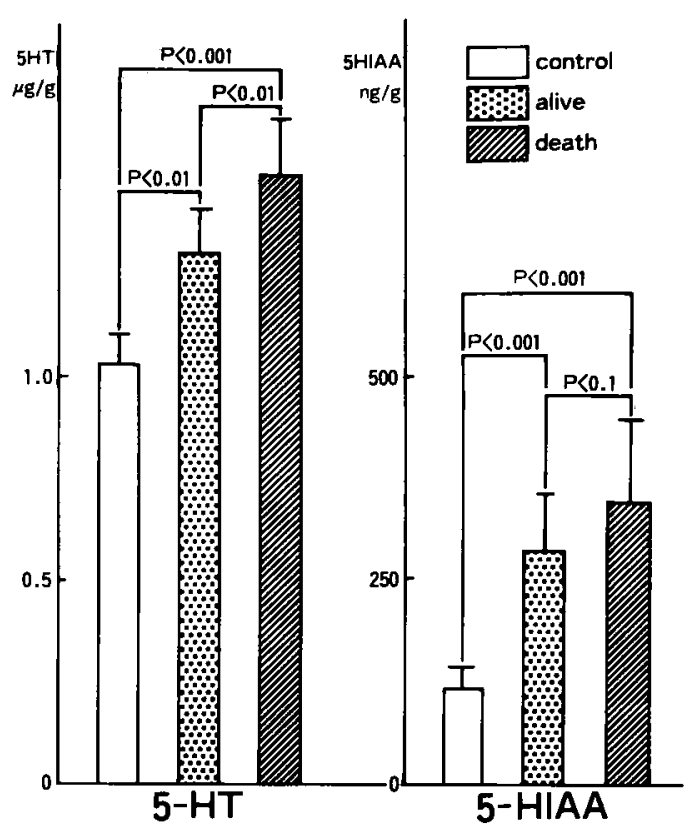

Fig. 5 Change of serotonin metabolites in brain of mice with acute hepatic failure.

control group ; $n=10$, alive group; $n=10$, death group; $\mathrm{n}=10$.



Fig. 6 Change of tryptophan and tryptamine metabolites in kidny of mice with acute hepatic failure.

control group; $n=10$, alive group; $n=10$, death group; $n=10$. 


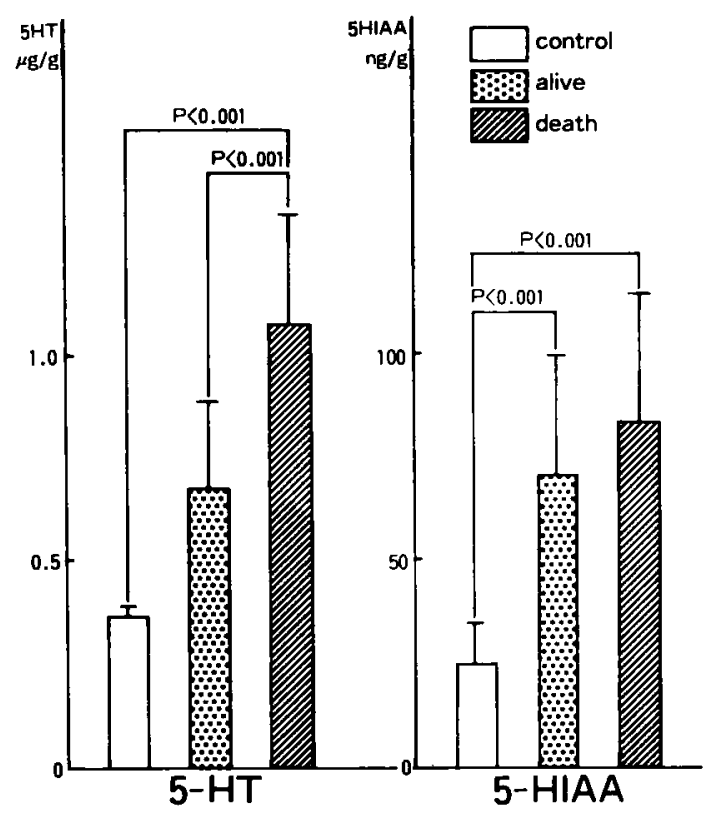

Fig. 7 Change of serotonin metabolites in kidny of mice with acute hepatic failure.

control group; $n=10$, alive group $n=10$, death group $; n=10$.

上りも TRM 代謝の增加率の方が大きかった。腎臓で は生存群に标いて 5-HIAA が, 死亡群において TRP, TRM，IAA，5-HT，5-HIAAが著しく上昇した。 こ れらの代謝産物の上昇は，前駆体である TRP の著し い上昇のため，5-HT，TRM 経路が代謝促進されたた めと考えられる。

さて,TRP の肝における主要代謝経路はキヌレニン 経路であるが, TRPからキヌレニンへの代謝に怙ける 第一段階の酳素であるトリプトファンピロラーゼは肝 障害で低下寸るといわれている(4). 従って，TRPの上 昇の理由はトリプトファンビロラーゼが肝内に和いて 阻害されるためであろう。

一般に肝性脳症の原因物質としては，フンモニフ， 低級脂肪酸,メルカプタン, フェノール類などの異常 代謝物の蓄積が報告されているが'131, 神経伝達物質の 異常やフェネチルフミンやオクトパミンなどの微量つ ミンの増加す知られている ${ }^{13)}$. なた脳内の意識を司る 部分での，頭著な 5-HT 代謝の立進が肝性脳症の発現 に関連があるとの報告すある5．しかし，今回の成績は TRP 代謝は脳内においては，5-HT 合成，TRM 合成 ともに促進されているが，5-HT 代謝よりるTRM 代 謝の方が著しく増加することが判明した。この点に関
しては, 肝性脳症との関係, その機序も含めて今後さ らに詳細な検討が必要と考える。

$$
\text { 文献 }
$$

1）下條点み，八巻敏雄：植物成長ホルモン(IAA)の 動物細胞に和ける作用及びその臨床的応用に関す る研究. 日消誌 $79: 2314-2322,1982$

2) Weissbach H, King W, Sjoerdsma A, et al: Formation of indole-3-acetic acid and tryptamine in animals. A method for estimation of indol-3-acetic acid in tissues. $\mathrm{J}$ Biol Chem $234: 81-86,1959$

3) 阪東慶一, 舟木正明, 神木照雄, 他: GCMS spectrometer による血清インドール酢酸の測定. 臨化 $10: 253-262,1981$

4) Yoshida K, Hirayama C: Clinical evaluation of serum levels of tryptophan in hepato-biliary disease. Clin Chim Acta 101 : 235-240, 1980

5）橋本 修, 斉藤公志郎, 小畠正夫, 他：肝性譄症に おける脳内セロトニン代謝異常に関する研究. 肝 缄 $21: 693-703,1980$

6) Yamada J, Sugimoto $Y$, Horisaka K : Elevation of serum indoleacetic acid levels in rats with experimental liver failure. J Pharmacobio Dyn 8: 780-784, 1985

7）児玉千枝, 杉本由美，山田 潤, 他 : 各種肝疾患患 者血清中のトリブトフォンおよびインドール酢酸 の検討. 日消誌 $82: 1277,1985$

8) Muro HN, Fernstrom JD, Wurtman RJ : Insulin, plasma amino acid imbalance and hepatic coma. Lancet $1: 722-724,1975$

9）渡辺明治, 長島秀夫：脳内芳香族 $ミ ノ$ 酸由来の 偽性神経伝達特質と肝性昏睡. 日本臨林 40 ： $784-790,1982$

10) Young SN, Lal $S$ : Tryptamine metabolism in hepatic coma. J Neural Transm $47:$ 153-161, 1980

11) Tsutsui H, Mizoguchi $Y$, Yamamoto S, et al: Studies on experimentally-induced acute hepatic failure : Possible involvement of activated liver adherent cells. In: Cells of the hepatic sinusoid. Edited by Krim A, Knook DL, Wisse E. Kupffer Cell Foundation, The Netherlands, 1985, p307-314

12) Yamada J, Sugimoto $Y$, Horisaka $K$ : Simultaneous determination of tryptophan and its metabolites in mouse brain by high- 
performance liquid chromatography with fluorometric detection. Anal Biochem 129 : 460-463, 1983

13) Fischer JE, Balderssarini RJ : False neurotrnasmitters and hapatic failure. Lancet 2: 75
$-79,1971$

14) Sato $Y$, Maruyama $M$ : The inhibition of tryptophan pyrolase synthesis in rat liver by carbon tetrachloride. J Biochem $72: 1129-1137$, 1972

\title{
Tryptophan metabolism in the liver, brain and kidney of mice with acute hepatic failure
}

\author{
Yasuhiro Mizoguchi, Chie Kodama, Norifumi Kawada, Yoshihide SaKagami, \\ Shuichi SeKI, Kenzo KobaYashi*, Sukeo Yamamoto** \\ and Seiji MORISAWA***
}

When heat-killed Propionibacterium acnes, a gram-positive anaerobe, is intravenously injected into mice followed by an intravenous injection of gram-negative lipopolysaccharide (LPS) 7 days later, most of the mice die of massive hepatic cell necrosis within 24 hours of LPS injection. Using this acute hepatic failure model, tryptophan metabolism in the liver, brain and kidney was studied. As a result, the tryptophan level remarkably increased in all three organs, and the metabolism of both the tryptamine pathway and serotonin pathway was induced. However, in the brain, the increase in tryptamine metabolism was higher compared to that of serotonin. This suggested that the metabolites of tryptamine may be involved encephalopathy.

* The Third Department of Internal Medicine, Osaka City University Medical School (Osaka)

** The Osaka Socio-Medical Center Hospital (Osaka)

**** The First Department of Biochemistry, Osaka City University Medical School (Osaka) 